\title{
OBITUARY
}

\section{PHILIP H. ADAMS}

By the death of Philip Adams on February 9 an association with Oxford Ophthalmology of nearly fifty years is severed. After leaving Lancing in the late 'nineties he came up to Exeter College, Oxford, and during his period there as an undergraduate spent much time working. at the Oxford Eye Hospital as a clinical assistant to his uncle, Robert Doyne, and for some part of this time filled the post of unqualified house surgeon there. After taking his degree and first M.B., he went to the London Hospital for clinical experience. While at the London he qualified M.B., Oxon, and in 1904 took the F.R.C.S., (Eng.). He then returned to Oxford and started ophthalmic practice in partnership with Robert Doyne, and was appointed Assistant Surgeon to the Oxford Eye Hospital.

The period 1900/1910 was a very active one in Oxford Ophthalmology. A Readership in Ophthalmology had recently been established with Doyne as the first Reader. The Diploma in Ophthalmology was inaugurated and the beginnings of the Oxford Ophthalmological Congress were in the making.

Into all these activities Adams entered to the full, and it can be said that the subsequent success of the Congress was largely due to his efforts, inspired by the genius and drive of Doyne and backed by the business and literary ability of Sydney Stephenson.

In 1912 on the retirement of Doyne, Adams was made Reader in Ophthalmology to the University and Senior Surgeon to the Hospital.

From then on for thirty years he was the lynch pin of Oxford Ophthalmology. He was responsible as Deputy Master for a large part of the arrangements for each annual Congress at the Oxford end; as Reader he was responsible for the course of study needed by. Statute for candidates for the Diploma of Ophthalmology, and he was at the same time, as Senior Surgeon to the Hospital, involved in day to day affairs relative to its efficiency. $\mathrm{He}$ also had a large private practice. He carried out all these manifold duties with great efficiency, but in a most self effacing manner. It would have been hard for anyone not knowing him intimately to guess the amount of work he shouldered.

He went through the post of Master of the Oxford Ophthalmological Congress for the period 1925/1927, and he delivered the Doyne Memorial Lecture in 1931. In 1944/1945 he was President of the Ophthalmic Section of the Royal Society of Medicine.

As a clinician, Adams was quite outstanding, showing much shrewdness in diagnosis and in managing patients. As an operator he was in the highest class. 




PHILIP H. ADAMS 
He had great charm of manner, and a most distinguished and handsome appearance. He was always immaculately turned out.

Adams retired from Oxford in 1941 and had made a home in the Eastern Counties, but he attended the Congress each year and it is a sad thought that we shall not see him there again.

\section{SIR H. LINDO FERGUSON}

By the death of Sir Lindo Ferguson on January 22, at Dunedin, New Zealand, the Ophthalmological Society of Great Britain lost its sole surviving foundation member.

Sir Lindo was born in London in 1858. His family moved to Ireland and, in 1873, at the age of 16, he entered the Royal College for Science of Ireland with a Royal Scholarship. He graduated in chemistry and then, turning to medicine, entered Trinity College.

After completing his arts course, he trained at Adelaide Hospital, qualified at the age of 22 and went into residence at St. Mark's Ophthalmic Hospital. After a period of study on the Continent, he held assistantships at various ophthalmic departments and, in 1883, he obtained his Fellowship of the Royal College of Surgeons of Ireland and graduated Doctor of Medicine at Trinity College.

Soon afterwards, for reasons of health, he travelled to New $Z$ ealand, and, finding an embryo medical school in Dunedin, decided to practise there. At this time he was the only ophthalmic surgeon in New Zealand or Australia and very soon his opinion and services were asked for from all quarters. In 1884 he opened the ophthalmic department at Dunedin Hospital and was appointed Lecturer in Ophthalmology two years later. For fifty-two years Sir Lindo served on the staff of the Hospital, always enjoying the esteem of his colleagues, his students and his patients. In 1914 he was appointed Dean of the Medical Faculty, and, realising that the rapidly growing Medical School was woefully lacking in accommodation, he set about the task of rebuilding. Years of hard work for Sir Lindo followed, and 1927 saw the Departments of Anatomy, Physiology, Pathology and Bacteriology all housed in a building which stands as a monument to him.

For twenty years he was a professional representative on the Otago University Council and for eight years a member of the Senate of the University of New Zealand. He was a foundation member of the Ophthalmological Society of the United Kingdom, an original member of the Royal Academy of Medicine in Ireland, an Honorary Fellow of the American College of Surgeons, a Foundation Fellow of the Australasian College of Surgeons, a member of the New Zealand Medical Council and a past President of the New Zealand Branch of the British Medical Association. He was Patron of the New Zealand Ophthalmological Society, founded in 1947. 